\title{
不均一地盤におけるダルシ一流速分布の 統計的性質と水みち形状に関する研究
}

\author{
齋藤 雅彦 1 - 倉本 拓哉 $2 \cdot$ 中川 啓 3 \\ 1 正会員 神戸大学助教 大学院工学研究科市民工学専攻（广657-8501 神戸市灘区六甲台町 1-1） \\ E-mail:msaito@kobe-u.ac.jp \\ 2 非会員＼cjkstart防衛省南関東防衛局調達部（†231-0003 神奈川県横浜市中区北仲通 5-57） \\ E-mail:t-kuramoto@s-kanto.rdb.mod.go.jp \\ 3 正会員 長崎大学教授 大学院水産・環境科学総合研究科（广 852-8521 長崎市文教町 1-14) \\ E-mail: kei-naka@nagasaki-u.ac.jp
}

\begin{abstract}
地質学的に同一とみなされる帯水層内においても，飽和透水係数等の物性值は空間的なばらつきを有す る.これにより, 流速分布にもばらつきが生じ, 局所的に流速の大きな部分（いわゆる水みち）が存在す る可能性がある。しかしながら，これらを現場観測等により精度よく把握することは事実上不可能であり， 通常の地下水・浸透流に関寸るシミュレーションではこのような不均一性は無視されている. 本研究では, 単純な矩形領域を対象に, 透水係数の空間分布モデルを用いて数值シミュレーションを行い, 透水係数の ばらつきの大きさ，空間解像度および解析領域のアスペクト比の違いが流速分布の統計的性質に与える影 響について考察した。 その結果，これらの関係は比較的簡易な数式で近似可能であり，また解像度を上げ ることによって局所的な水みちが表現されることを示した.
\end{abstract}

Key Words: groundwater, hydraulic conductivity, geostatistical model, numerical simulation

\section{1. 序論}

近年，地下水・浸透流問題を解析するための解析手法 は急速に発展した. 多くのソフトウェアが開発され，さ らに計算機の高速化・大容量化によって, 数理的にきわ めて精緻な解析モデルを比較的容易に構築することも可 能となった. 一方, 同一の帯水層内においても, 飽和透 水係数等の地盤物性值は空間的なばらつきを有すること が知られている 1)2 2. これにより，流速分布にもばらつ きが生じ，局所的に流速の大きな部分（いわゆる水み ち）が存在する可能性があるが 324，このような地盤物 性值のばらつきを現場観測等によって精度よく把握する ことは事実上不可能である. このため, 数值シミュレー ションの際には，限られた調査地点において得られた調 查結果から，地質学的に同一と見な寸ことができる帯水 層については物性值も一定と仮定せざるを得ない，つま り，通常は地盤情報については極度に単純化されている ため，通常のシミュレーションによって得られる結果は， あくまで「平均的」なものであり，必ずしも流机場の詳 細を再現し得るものではないことに留意しなければなら
ない.

また，このような地盤物性值のばらつきに関しては, 統計的性質に基づく様々な空間分布モデルが提案されて いる5. しかしながら，これらの多くは定常確率場を仮 定したものであり，シミュレーションモデルに導入する 際には, 解析スケールや解析上の解像度に応じた適切な 統計パラメータの設定が困難であることが指摘されてい る ${ }^{4}$. これに対して，齋藤・川谷の》は，透水係数分布 に関する理論的考察に基づいて, 非定常確率場モデルの 一種である自己相似型の空間モデル（以下 $f$-ら型モデル と記す）を提案し，同モデルが実地盤における透水係数 の空間分布特性を適切に模擬し得るとともに，解析スケ 一ルや解像度の違いを容易にモデルに反映させることが 可能であることを確認している.

本研究では, 単純な矩形領域を対象に, 透水係数の空 間分布モデルとして $f$-ら型モデルを用いて数值シミュレ ーションを行い，透水係数のばらつきの大きさ，空間解 像度および解析領域のアスペクト比の違いが流速分布の 統計的性質に与える影響について考察するとともに，水 みち形状に関する検討を試みる。 


\section{2. 基礎方程式と透水係数の空間分布モデル}

\section{(1) 基礎方程式}

本研究で取り扱う浸透場は、帯水層厚が一定の平面 2 次元等方性定常被圧浸透場とする. ここで, 涌き出し・ 吸込みはないものとし, 運動方程式はダルシー則に従う とすると，基礎方程式は連続式とダルシー則より以下の ように表される.

$$
\frac{\partial}{\partial x}\left(T \frac{\partial h}{\partial x}\right)+\frac{\partial}{\partial y}\left(T \frac{\partial h}{\partial y}\right)=0
$$

ここに， $x, y$ は空間座標， $h$ はピエゾ水頭， $T$ は透水量係 数 $(=B k), B$ は帯水層厚, $k$ は飽和透水係数である.

境界条件は，水頭が規定される境界では，

$$
h=h_{b}
$$

であり，流束が規定される境界では，

$$
-\left(T \frac{\partial h}{\partial x} n_{x}+T \frac{\partial h}{\partial y} n_{y}\right)=q_{b}
$$

である. $q_{b}$ は外部境界における単位長さ当たりの流量, $n_{x}$ と $n_{y}$ は境界にたてた外向法線の方向余弦である.

ここで，代表長さ 10 および飽和透水係数の代表值 $k_{0}$ を 用いて, 式(1)の諸量について以下のように無次元量を 定義する.

$$
X=\frac{x}{l_{0}}, \quad Y=\frac{y}{l_{0}}, \quad H=\frac{h}{l_{0}}, \quad K=\frac{T}{B k_{0}}
$$

これにより，式(1)を書き換えると，以下のようになる.

$$
\frac{\partial}{\partial X}\left(K \frac{\partial H}{\partial X}\right)+\frac{\partial}{\partial Y}\left(K \frac{\partial H}{\partial Y}\right)=0
$$

境界条件は，水頭が規定される境界では，

$$
H=H_{b}=h_{b} l_{0}
$$

であり，流束が規定される境界では，以下のようになる.

$$
-\left(K \frac{\partial H}{\partial X} n_{x}+K \frac{\partial H}{\partial Y} n_{y}\right)=\frac{q_{b}}{B k_{0}}
$$

\section{（2）透水係数の空間分布モデル 6,7)}

不均一場を生成するために，透水係数の不均一性を表 わす空間分布モデルとして $f$-型モデルを使用する. こ れは $\log _{10} K$ のパワース゚クトル密度関数が以下のように

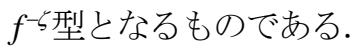

$$
S(|f|) \propto|f|^{-\zeta}
$$

ここに $f$ は空間周波数ベクトル， $S(|f|)$ はパワースペ クトル密度，らは空間的な相似性を表わすパラメータで あり，〔空間次元，すなわち2次元モデルでは と完全な自己相似性を持つ。これは，定常確率場を仮定 した空間分布モデルのように特定のスケール（例えば相

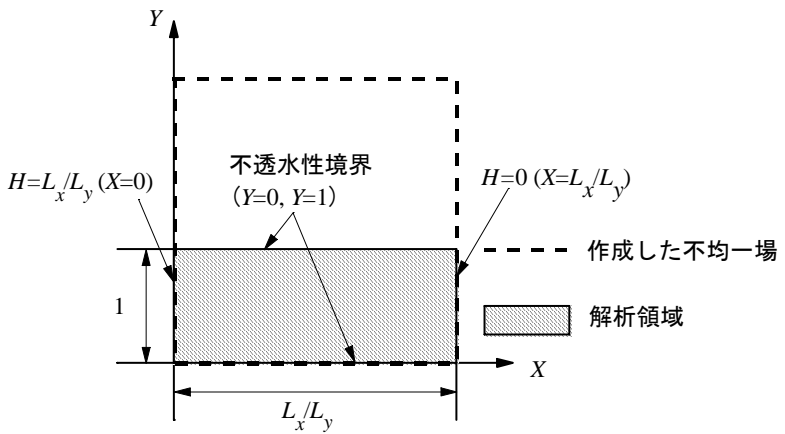

図-1 解析領域と境界条件

\begin{tabular}{|c|l|}
\multicolumn{2}{c}{ 表-1 パラメータのパターン } \\
\hline$N$ & $4,5, \quad 6,7, \quad 8,9$ \\
\hline$\lambda_{K}$ & $0.02,0.04,0.06,0.08,0.10$ \\
\hline$L_{X} L_{Y}$ & $1 / 8, \quad 1 / 4,1 / 2, \quad 1,2,4,8$ \\
\hline
\end{tabular}

関長）を持たないため, 無次元場にも適用可能である.

また，本モデルでは $\zeta=$ 空間次元とすると， $\log _{10} K$ は 正規分布に従い(Kは対数正規分布 $)$, 同質地盤におけ る $\log _{10} K$ の分散 $\sigma_{K}^{2}$ と解像度 (=要素数) $M$ の間には式 (9)の関係が成り立つため, 解像度に応じた同質地盤を 容易に表現可能である 6)-8).

$$
\sigma_{K}^{2}=\lambda_{K} \log _{10} M
$$

ここに $\lambda_{K}$ は不均一性の大きさを表わす無次元パラメー タである.

\section{3. 解析条件}

\section{(1) 解析領域と境界条件}

本研究では，まず正方形領域の不均一場を FFTによ つて生成する.つぎにアスペクト比 $L_{X} L_{Y}$ を決め, 図-1 に示すように生成された正方形の不均一場からアスペク 卜比に応じて矩形の解析領域分の透水係数分布をあては める. このとき, 式(4)における代表長さは $l_{0}=L_{y}$ とする。 また，境界条件は図-1 に示すように平均動水勾配が 1.0 となるように $X=0$ で $H=L_{X} / L_{Y}, X=L_{X}$ で $H=0$ とし,$Y=0$ および $Y=1$ では不透水性境界 $\left(q_{b}=0\right)$ とする.

\section{（2）浸透流解析}

解析ケースは，表-1に示すように透水係数のばらつき $\lambda_{K}$ を 5 ケース, アスペクト比 $L_{X} L_{Y}$ を 7 ケース設定する. また，はじめに生成する正方形場の要素数は $M_{0}=2^{N} \times 2^{N}$ となり，各アスペクト比に対応する要素数が式(9)にお ける解像度 $M\left(M \leqq M_{0}\right)$ となるが，要素サイズについて はアスペクト比に関わらず $N$ に応じて決定される. こ れより, 各ケースの要素サイズを表すパラメータとして は $N$ を用いる. 

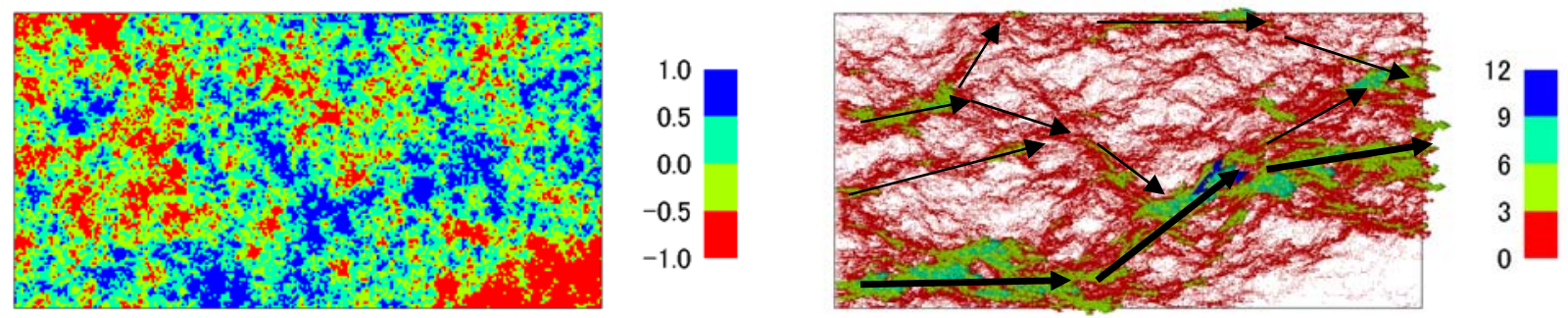

(a) $\lambda_{K}=0.06, \quad N=8(M=32,768), L_{X} / L_{Y}=2$
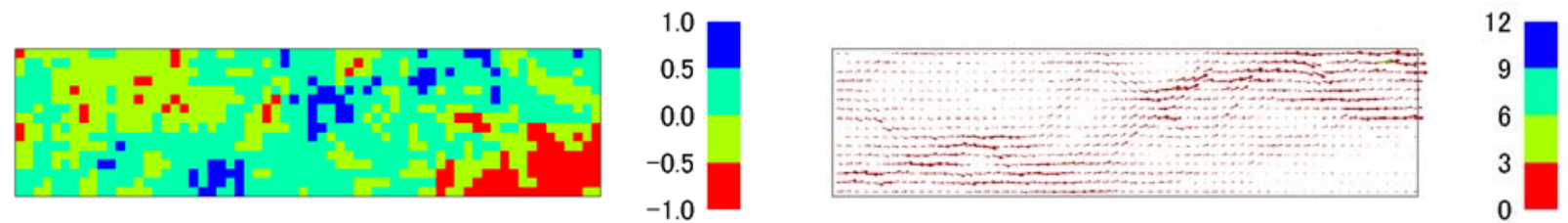

(b) $\lambda_{K}=0.04, N=6(M=1,024), L_{X} / L_{Y}=4$

図-2 透水係数分布とダルシー流速分布（左 ; 透水係数分布, 右 ; ダルシー流速分布)

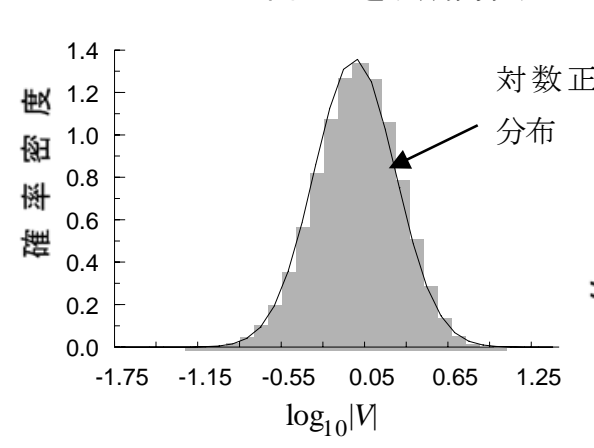

図-3＼cjkstart流速ベクトルの大きさの頻度分布の一例 $\left(N=9, \quad \lambda_{K}=0.04, \quad L_{X} / L_{Y}=1\right)$

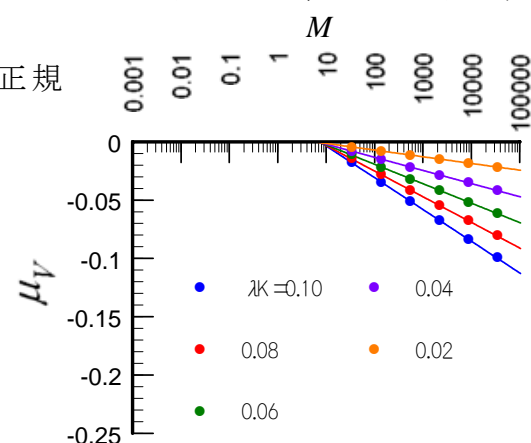

(a) $L_{X} L_{Y}=1 / 8$

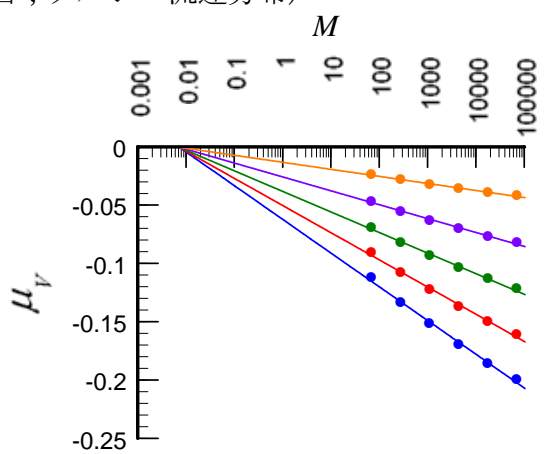

(b) $L_{X} / L_{Y}=4$

図-4 解像度 $M$ と $\mu_{V}$ の関係

また， $\log _{10} K$ の平均值 $\mu K$ は $0.0\left(K_{A V}=1.0\right)$ とする. これ らの組み合わせにより 210 通りの無次元不均一場をそれ ぞれ 100 個生成する.つぎに，それぞれの場に対して有 限要素法による浸透流解析を行い, 流速分布を求める.

図-2 に透水係数分布と流速分布の一例を示寸。これ より，ばらつきが大きく，また解像度が大きい場合には 図-2(a)の矢印で示すように，局所的に流速の大きい部 分である水みちが形成されているのがわかる．また，図 -3 は，得られたダルシー流速ベクトルの大きさ|Vの対 数変換值 $\log _{10}|V|$ 頻度分布の一例である. これより，頻 度分布は概ね対数正規分布に従っていることがわかる.

\section{4. 解析結果と考察}

\section{(1) ダルシ一流速の平均值について}

まず, $\log _{10} \mid$ |平均值を $\mu \nu$ とし, その性質について検 討する. 図-4 は，それぞれ $L_{X} L_{Y}=1 / 8$ および $L_{X} L_{Y}=4$ に対
する解像度 $M$ と $\mu N$ の関係を示したものである. これよ り, 解像度が大きくなるとダルシ一流速の平均值が低下 する傾向が見られ，両者の関係は対数関数で近似可能で あることがわかる，これは，先に示したように，解像度 が大きくなると局所的な水みち部分がより明確になり， その他の大部分の流速が相対的に小さくなるためと考え られる. 加えて, 透水係数のばらつき $\lambda_{K}$ が大きくなる

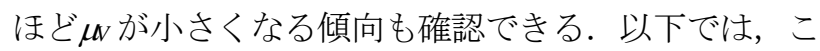
れらの関係を次式で近似することを試みる.

$$
\mu_{V}=\lambda_{m} \log \left(\frac{M}{\delta_{m}}\right)
$$

ここに， $\lambda_{m}$ と $\delta_{m}$ はフィッテイングパラメータである.

図-5 に一例として $L_{X} L_{Y}=1 / 2$ における $\lambda_{K}$ と $\lambda_{m}$ の関係を 求めたものを示す. これより, $\lambda_{K}$ と $\lambda_{m}$ の関係は次式の ように原点を通る直線で近似可能であることがわかる.

$$
\lambda_{m}=\varepsilon_{m} \lambda_{K}
$$




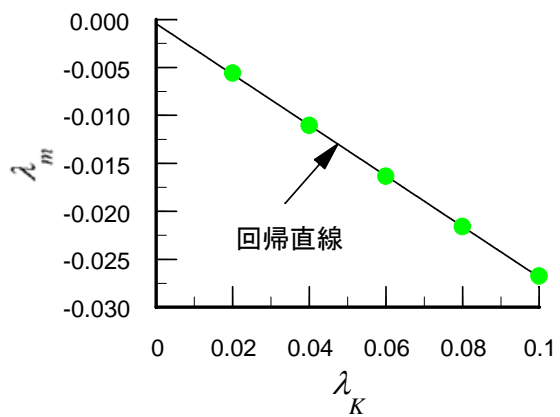

図-5 $L_{X} / L_{Y}=1 / 2$ における $\lambda_{K}$ と $\lambda_{m}$ の関係

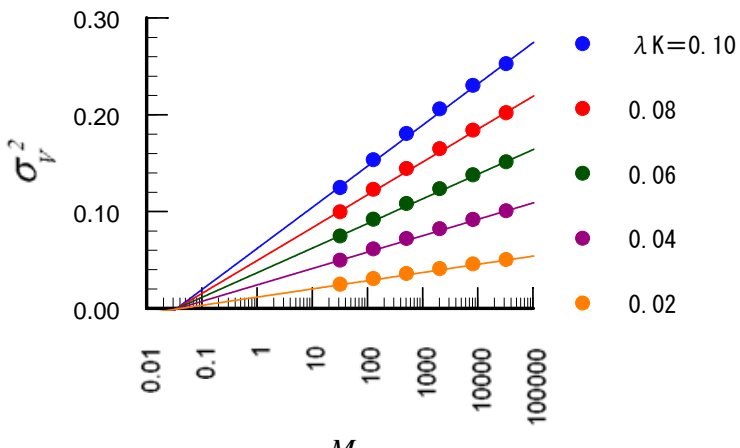

(a) $L_{X} / L_{Y}=1 / 8$

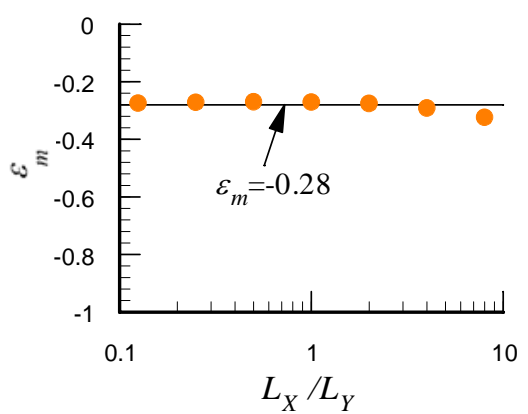

図-6 アスペクト比と $\varepsilon_{m}$ の関係

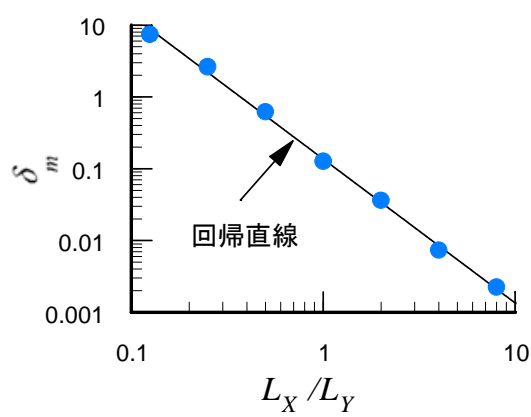

図-7アスペクト比と $\delta_{m}$ の関係

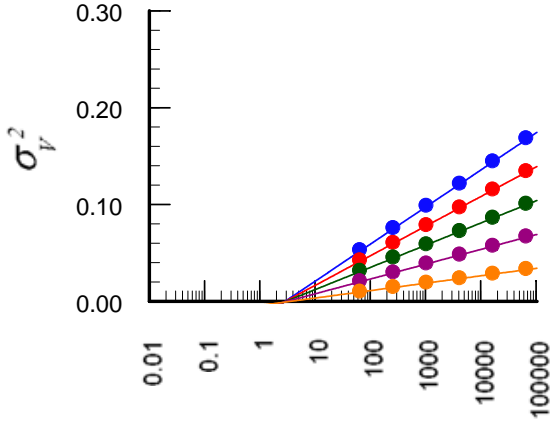

$M$

図-8 解像度 $M$ と $\sigma_{V}^{2}$ の関係

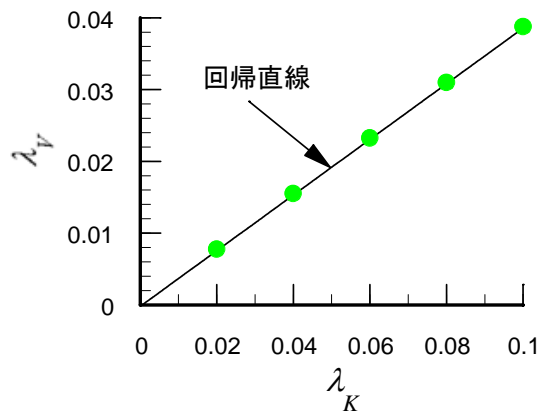

図-9 $L_{X} / L_{Y}=1 / 2$ における $\lambda_{K}$ と $\lambda_{V}$ の関係

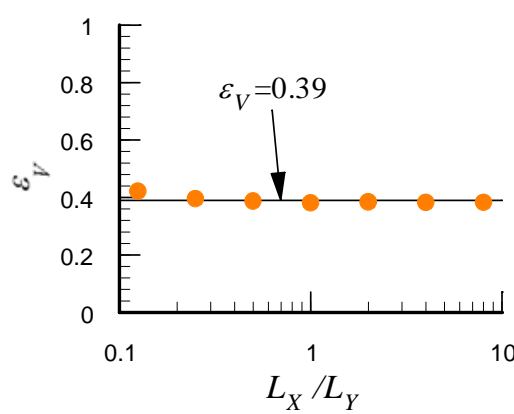

図-10 アスペクト比と 8 の関係

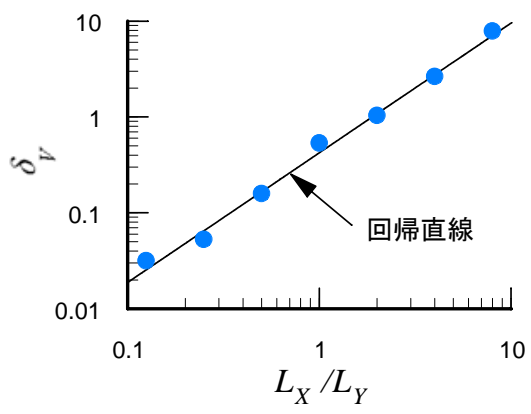

図-11アスペクト比と $\delta$ の関係
ここに， $\varepsilon_{m}$ はフィッティングパラメータである.また, 図-6 は，アスペクト比と $\mathrm{m}$ の関係を求めたものである

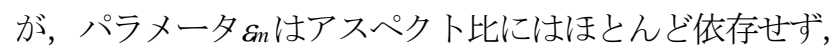
概初一定值 $\left(\varepsilon_{m}=-0.28\right)$ で近似可能と考えられる.

一方， $\delta_{m}$ については，図-4において $\mu_{N}=0$ となる $M$ の 值に相当するが，図-4(a)，(b)より $\lambda_{K}$ には依存せず，ア スペクト比のみに依存していることがわかる. 図-7 は, アスペクト比と $\delta m$ の関係を示す。これより, 両者の関 係は次式で近似可能である.

$$
\delta_{m}=0.137\left(\frac{L_{X}}{L_{Y}}\right)^{-2.00}
$$

\section{（2）ダルシ一流速の分散について}

$\log _{10}|\eta|$ 分散を $\sigma V^{2}$ とし，その性質について考察する。 図-8 は，それぞれ $L X L Y=1 / 8$ および $L X L_{Y}=4$ に対する解像 度 $M$ と $\sigma \nu^{2}$ の関係を示したものである. これより, 解像
度が大きくなるほど分散は大きくなることがわかる。こ れは，ここで用いている透水係数の空間分布モデルでは， 式(9)で示したように，透水係数の分散 $\sigma K^{2}$ が解像度に依 存するため，これと同様の性質を持つためである.

また，以下では， $\lambda_{K} ， M$ ，および $L X L Y$ と $\sigma v^{2}$ の関係の 評価を試みる. 図-8 より, これらの関係は式(10)と同様 に，次式で近似可能と考えられる.

$$
\sigma_{V}{ }^{2}=\lambda_{V} \log \left(\frac{M}{\delta_{V}}\right)
$$

ここに， $\lambda_{V}$ と $\delta$ はフィッテイングパラメータである.

図-9に $L_{X} L_{Y}=1 / 2$ における $\lambda_{K}$ と $\lambda_{V}$ の関係を示寸. 式(11) と同様に，両者の関係も以下のように原点を通る直線で 近似可能である. 


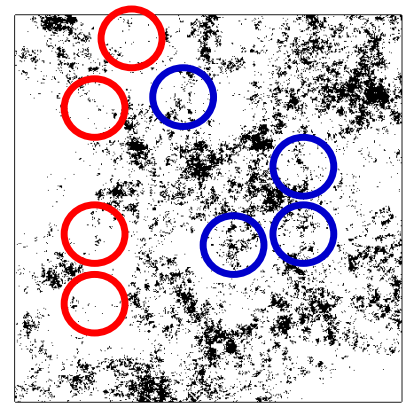

(a) 透水係数分布 $\left(K>\mu_{K}+\sigma_{K}\right)$

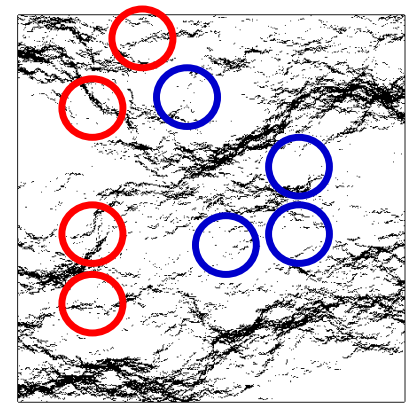

(b) 流速 $|V|$ の分布 $\left(V>\mu_{V}+\sigma_{V}\right)$

図-12 透水係数分布と流速分布 $\left(\lambda_{K}=0.06, N=9, L_{X} L_{Y}=1\right)$

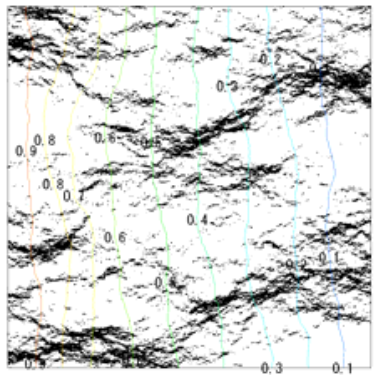

(a) $\lambda_{K}=0.02$

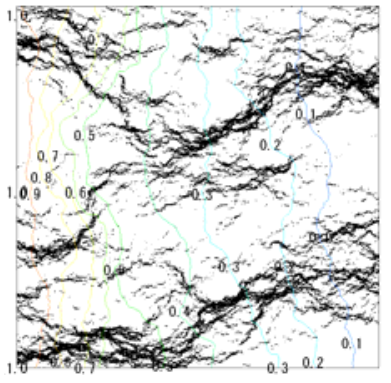

(b) $\lambda_{K}=0.10$
図-13 $\lambda_{K}$ の相違に対寸る流速分布と水頭分布の比較 $\left(N=9, V>\mu N^{+} \sigma v\right)$

$$
\lambda_{V}=\varepsilon_{V} \lambda_{K}
$$

ここに， $\varepsilon_{V}$ はフィッティングパラメータである.また, 図-10 にアスペクト比と $g v$ の関係を示す，図-6 と同様に パラメータ $\varepsilon_{V}$ はアスペクト比に依存せず，ほぼ一定值 $(g v=0.39)$ で近似可能と考えられる.

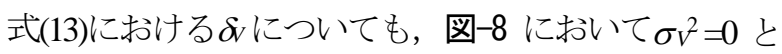
なる $M$ の值に相当し， $\lambda_{K}$ には依存せず，アスペクト比 のみに依存していることがわかる．図-11 は，アスペク ト比と $\delta$ Vの関係を示寸．これより，両者の関係は次式 で近似可能である.

$$
\delta_{V}=0.438\left(\frac{L_{X}}{L_{Y}}\right)^{1.353}
$$

以上の検討により，矩形領域の 1 次元的流れ場におい ては，ダルシー流速の大きさの平均值 $\mu$ および分散 $\sigma_{V}{ }^{2}$ と，透水係数のばらつきの大きさ $\lambda_{K}$ ，解像度 $M$ ，および アスペクト比 $L_{X} L_{Y}$ の関係は, 両者とも同様の関数形で 比較的簡易に表現可能であることがわかる.

\section{（3）水みちの性質について}

まず，透水係数の対数值と流速ベクトルの大きさ $\log _{10}|\mathrm{Y}|$ 分布を比較する. 図-12 は，両者とも平均值+標 準偏差より大きい要素のみを黒く着色して示しているが, 赤○印で囲まれた部分のように透水係数の小さい部分に も流速の大きい部分が存在し，また青○印で示した部分 のように透水係数が大きくても流速は小さい部分が現れ,

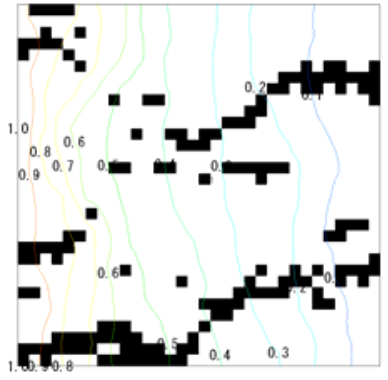

(a) $N=5$

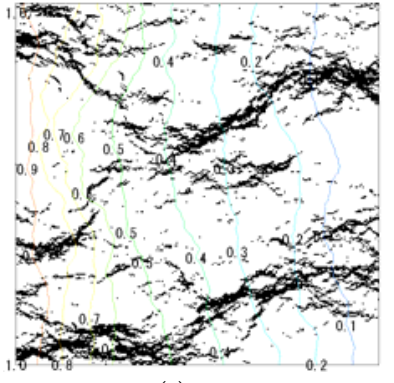

(b) $N=8$
図-14 $N$ の相違に対する流速分布と水頭分布の比較 $\left(\lambda_{K}=0.06, \quad V>\mu_{N}+\sigma_{V}\right)$

流速ベクトル分布は水みち状を示していることが分かる.

つぎに，図-13 は同一の解像度で異なる $\lambda_{K}$ に対する流 速分布と水頭分布を比較したものである．ここで，流速 分布は, 図-12 と同様に平均值+標準偏差より大きい部 分のみを示している. まず， $\lambda_{K}=0.02$ （透水係数のばら つきが小さい場合）では，等水頭線はほぼ等間隔となっ ているのに対し， $\lambda_{K}=0.10$ (透水係数のばらつきが大き い場合）では，上流側の間隔が狭く，下流側が広くなっ ており，顕著な相違が生じている．これに対し，流速分 布が大きい部分については，両者は概初同様に分布して おり，水みち形状については，透水係数分布のばらつき

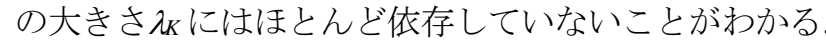
一方，図-14 は，同一の $\lambda_{K}$ で解像度が異なる場合の水頭 分布と流速分布を比較したものである. 水頭分布につい ては，解像度の違いにはほとんど依存せず，等水頭線の 形状は概ね同様となっている。これは，浸透場のばらつ

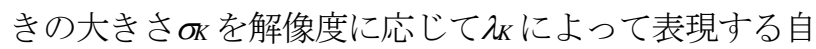
己相似型空間分布モデルの特徽の一つである 》。一方, 流速分布については解像度を大きくするに従って，局所 的に流速の大きい部分がより多く現れている。これより， 比較的粗い解像度では，主要な水みちのみを捉え，解像 度を大きくするに従ってより詳細な水みちが得られるこ とがわかる．これは，透水係数分布モデルの自己相似性 に由来するものと考える．なお，ここでは発生させた 100 通りの透水係数分布のうち，代表的な一例について 考察しているが，その他の分布パターンについても概ね 共通の性質を有することを確認している. 


\section{5. 結論}

本研究では，単純な矩形領域を対象に，透水係数の空 間分布モデルとして $f$-ら型モデルを用いて数值シミュレ ーションを行い，透水係数のばらつきの大きさ，空間解 像度および解析領域のアスペクト比の違いが，流速分布 の統計的性質に与える影響について考察するとともに, 水みち形状に関する検討を試みた。これにより得られた 結果を以下にまとめる.

1）ダルシー流速の平均值は，解像度が大きくなると低 下寸ること，また，透水係数のばらつきが大きくな るほど平均值は小さくなる傾向を確認した，加えて， 透水係数のばらつき，空間解像度，およびアスペク

ト比と，ダルシー流速の平均值の関係を明らかにし， 定量的に評価する簡易な方法を示した.

2）ダルシー流速の分散は解像度が大きくなると増加す ること，透水係数のばらつきが大きくなるほど分散 も大きくなる傾向を確認した．加えてダルシー流速 の分散についても，平均值と同様に透水係数のばら つき，空間解像度，およびアスペクト比との関係を 明らかにし，定量的に評価する簡易な方法を示した。 3) 水みちの性質について検討し, 透水係数が大きい部 分と流速の大きい部分は必ずしも一致せず，流速べ クトル分布は明らかに水みちを形成することを示し た．また，水みち形状については，透水係数分布の ばらつきの大きさにはほとんど依存しないこと，ま た，比較的粗い解像度では，主要な水みちのみを捉 え, 解像度を大きくするに従ってより詳細な水みち が得られることを示した。

これらの結果は，単純な 2 次元矩形領域を対象とした ものであり，解析対象を近似的に矩形領域で表現可能な 場合に対しては有効と考える.また，より複雑な解析領
域や 3 次元流れ場についても，水みちの性質に関する部 分については，定性的には同様と考える.これより，地 盤を均一と仮定した解析により得られたダルシー流速分 布に対して，高精度ではないが実際にはどの程度のばら つきを考慮すべきかを定量的に把握することが可能であ ると考える。一方，このような結果が得られた詳細なメ カニズムについては不明な点が多く, 今後の検討課題と したい.

謝辞 : 本研究は JSPS 科研費（26550069）の助成を受けたもので ある.ここに記して謝意を表す。

\section{参考文献}

1) Freeze, R. A. : A stochastic-conceptual analysis of onedimensional groundwater flow in nonuniform homogeneous media, Water Resour. Res., Vol.11, No.5, pp.725-741, 1975.

2) Smith, L. and Freeze, R. A. : Stochastic analysis of steady state groundwater flow in a bounded domain, 2 . Two-dimensional simulations, Water Resour. Res, Vol.15, No.6, pp.1543-1559, 1979.

3) 水夕ち研究会：水みちを探る-井戸と涌泉と地下水 の保全のために-，けやき出版，69p., 1992.

4) 水みち研究会: 井戸と水みち, 北斗出版, 202p., 1998.

5) de Marsily, G. : Quantitative Hydrogeology, Academic Press Inc., 303p., 1986.

6) 齋藤雅彦，川谷健 : 透水係数の空間分布モデルの適用性 に関する一考察，土木学会論文集，No.694， III-57， pp.245-258, 2001.

7) 齋藤雅彦，川谷健 : 透水係数の空間分布に関する理論的 考察，土木学会論文集，No.645，III-50，pp.103-114， 2000.

8) 齋藤雅彦，西村由紀子，中川啓：自己相似型不均一地盤 モデルを用いた巨視的分散長の定量的評価に関する研究， 地下水学会誌, Vol.53, No.4, pp.343-355, 2011.

(2016. 9.30 受付)

\title{
STUDY ON STATISTICAL PROPERTIES OF DARCY VELOCITY DISTRIBUTION AND FORM OF WATER PATH IN NON-UNIFORM FIELD
}

\author{
Masahiko SAITO, Takuya KURAMOTO and Kei NAKAGAWA
}

The physical propertieses of aquifer such as hydraulic conductivity vary spatially even if the aquifer seems to be uniform. This causes spatial varieties of Darcy velocity distribution, and water path flow may exist in the aquifer. However, it is impossible to grasp the spatial distribution of hydraulic properties by field test, and such an inhomogeneity is ignored in the numerical simulation for groundwater flow. In this study, numerical simulations were carried out using the spatial distribution model of hydraulic conductivity for simple rectangular domains. And the influences of the spatial resolution and the aspect ratio of the domains for statistical property of the velocity distribution were investigated. It was shown that local water path can be expressed by numerical simulation using spatial distribution model of hydraulic conductivity. 